\title{
Sustainable use of the boreal Prince Albert Model Forest in Saskatchewan
}

\author{
O.T. Bouman ${ }^{1}$, G. Langen ${ }^{1}$ and C.E. Bouman ${ }^{2}$
}

Canada recently embarked on a model forest program that is guided by the notion of sustainable development. Ten model forest sites have been established at operational scales $(0.1-1.5$ million ha) in different ecoregions since 1992 . This study presents a framework for advancing both the human welfare and environmental dimensions of sustainable forest use by a localized multi-stakeholdership of First Nations, government and industry in the boreal Prince Albert Model Forest, Saskatchewan. The pressure on the local forest environment has been rising due to timber harvest and tourism. Human welfare has been influenced strongly by colonial legacies such as racial divisions, territorial boundaries, and centralized forest administration. The landbase, productivity and forest value approaches are proposed to advance sustainable forest use; but current data availability favours the landbase approach. Analysis of forest inventory data suggests that management needs to plan for a significant aggregation of harvest areas to sustain ecological and cultural functions which depend on large and continuous patch size. Forest policy-making must address ownership issues, local economic development, and economic philosophies of the stakeholders in order to overcome the colonial legacies and to redefine management responsibilities. The study proposes that the currently dominating government-owned management concepts should evolve into a more localized concept of ownership and management that can be sustainably supported and financed by forest stakeholders, governments, and local communities.

Key words: sustainable development, boreal forest, patch size, forest policy-making, stakeholder, First Nation, community
Le Canada a récemment mis en place un programme de forêt modèle qui repose sur la notion de développement durable. Dix sites de forêt modèles ont été établis à une échelle opérationnelle (0.1-1.5 millions d'ha) dans différentes écorégions depuis 1992. Cette étude présente un cadre de travail permettant de faire progresser à la fois le mieux-être humain et les dimensions environnementales de l'utilisation durable des forêts, établi par un groupe de décideurs comprenant les Premieres Nations, le gouvernement et l'industrie, et regroupé autour de la forêt modèle de Prince Albert en Saskatchewan. La pression exercée sur l'environnement forestier local s'est accentuée par suite de la récolte forestière et du tourisme. Le comportement humain a été fortement influencé par l'héritage colonial comprenant entre autre les barrières raciales, les limites territoriales, et la gestion centralisée des forêts. Les avenues selon le territoire forestier, la productivité et les valeurs forestières sont proposées afin de faire progresser l'utilisation durable des forêts; mais les données actuellement disponibles favorisent l'approche selon le territoire forestier. L'analyse des données d'inventaire forestier laisse entendre que la gestion doit avoir en main un plan permettant une agrégation significative des zones de récolte afin de maintenir les fonctions écologiques et culturelles qui dépendent en grande partie sur des blocs continus de dimensions importantes. L'élaboration de politiques forestières répond aux questions de droits de propriété, de développement de l'économie locale, et de philosophies économiques des décideurs de façon à surmonter l'héritage colonial et à redéfinir les responsabilités des gestionnaires. L'étude propose que le concept actuel dominé par la propriété gouvernementale devrait évoluer vers un concept de propriété et de gestion plus locales qui puisse être supporté et financés de façon durable par les décideurs forestiers, les gouvernements et les communautés locales.

Mots clés: développement durable, forêt boréale, dimension des blocs, élaboration de politiques, décideurs, Premières Nations, communauté

\section{Introduction}

The notion of sustainable development has received increasing attention in recent years, e.g. at the UNCED conference in Rio de Janeiro in 1992. Although sustainable forestry has a long history, it has not been pervasive and adaptive enough to halt depreciation, degradation and destruction of the world's natural forests. This raises concern because natural forests still are a major resource for the global forest-product market. In particular, global trade models indicate a rising pressure on boreal forests (Perez-Garcia 1993) which represent a significant portion of the world's remaining natural forests. Canada recently embarked on a sustainable development initiative in the forestry sector by creating model forests at operational scales $(0.1-1.5$ million ha) in different ecoregions (Brand and LeClaire 1994; Natural Resources Canada 1994).

${ }^{1} \mathrm{c} / \mathrm{o}$ Prince Albert Model Forest Association, Prince Albert, Saskatchewan, Canada S6V 7G3.

${ }^{2} \mathrm{c} / \mathrm{o}$ Won Ska Cultural School, Prince Albert, Saskatchewan, Canada S6V $2 \mathrm{H} 1$.
Sustainable development has human welfare and environmental dimensions (Pantin 1991), i.e., anthropocentric and ecocentric dimensions (Rotmans et al. 1994). Both aspects are addressed in the Prince Albert Model Forest by way of partnership among forest stakeholders and provision of scientific/technical support. A partnership of seven stakeholders was formed in 1993, and a $3,150 \mathrm{~km}^{2}$ area in north central Saskatchewan was declared to be the Prince Albert Model Forest. This part of the boreal forest has become a regional focal point for stakeholder dialogue on forest use issues, and for research and development in forest socio-economics and ecology. As such, the activities in the Prince Albert Model Forest aim at operationalizing the notion of sustainable development in a distinct boreal context.

The purpose of this paper is to provide a description of the Prince Albert Model Forest and its most prominent sustainability challenges as well as management structure and process. The local management situation and data availability is then summarized together with the approaches that have been proposed to innovate and operationalize the management of forests towards sustainable use. 


\section{Site Description}

The Prince Albert Model Forest is within the mixedwood section of the southern boreal forest bordering the Canadian prairies (Fig. 1). A dry and cold climate has created a forest of low productivity: Kabzems et al. (1986) estimated an average timber volume of $108 \mathrm{~m}^{3} \mathrm{ha}^{-1}$ for the mixedwood section in Saskatchewan. Site conditions and forest productivity, however, vary in the mosaic of generally coarse textured soils on fluvio-glacial deposits and glacial tills, and gently rolling terrain with poorly drained lowlands and well drained uplands (Anderson and Ellis 1976).

The forest is dominated by jack pine (Pinus banksiana Lamb.), aspen (Populus tremuloides Michx.), black spruce (Picea mariana BSP.) and white spruce (Picea glauca Voss). Wildfire is the natural process that creates small to large contiguous, even-aged forest stands and is the principal shaping force for biological diversity at the landscape level (Kimmins 1992).

About half of the model forest area of $3,150 \mathrm{~km}^{2}$ falls within the boundaries of Prince Albert National Park, which was created under federal legislation in 1927. Most of the remaining area lies within provincial jurisdiction ("Crownland"). The Montreal Lake Cree Nation covers about $2 \%$ of the model forest landbase. The timber resources within the Crownland portion of the model forest have been assigned to one industrial company under a forest management licence agreement since 1968. Industry uses timber for pulp and paper and lumber production.

Forestry practices include timber harvesting, with clear cutting being the preferred method (Fig. 2), followed by natural regeneration and/or planting of commercial tree species following various site preparation techniques. About $50 \%$ of the harvested area has been planted with jack pine and white spruce. The average road density ranges from $0.2 \mathrm{~km}$ per $\mathrm{km}^{2}$ in unmanaged areas to about $0.8 \mathrm{~km}$ per $\mathrm{km}^{2}$ in managed areas. Thus the Prince Albert Model Forest has not been managed intensively for timber production while a large portion has been set aside for nature conservation and recreation.

\section{Local Sustainability Challenges}

The two major challenges for land use planners and managers in Saskatchewan are a rising use of forest resources and a strong colonial legacy. Most of the current Canadian forestry and conservation literature concentrates on resource use pressure and carrying capacities of ecosystems, but the two challenges are also important, and need to be resolved in order to ensure sustainable forest use in the Prince Albert Model Forest. This aspect has been emphasized in recent research on co-management of natural resources (Notzke 1994; Thomas and Schaefer 1991), and with the concept of community forests(Duinker et al. 1994).

It is assumed that the pressure on the boreal forest of western Canada will continue to rise. This would not only have ecological and environmental consequences, but it would also represent an unprecedented social challenge, because the region is the homeland of large aboriginal populations.

\section{Colonial Legacy}

The Prince Albert Model Forest is almost entirely state-owned except for the Cree community of Montreal Lake Cree Nation. Forest administration rests completely with government agencies. The demographic situation is more unique as it shows a rapid growth of the aboriginal community (Fig. 3).

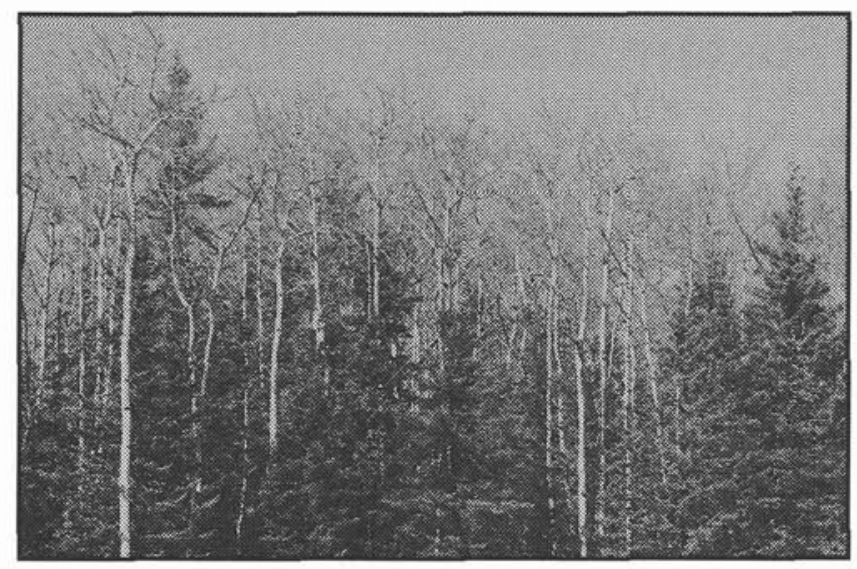

Fig. 1. Typical aspen spruce phase in the successional development of the boreal Prince Albert Model Forest, SK.

Walker (1995) referenced federal statistics that show a low labour force participation rate of $50 \%$, and an extremely high incarceration rate ( $66 \%$ of total jail admissions) for native people in Saskatchewan. These indicators clearly describe a socially and economically divided society. This is further substantiated by the fact that the majority of Saskatchewan's Indians (about 75\%) are of single ethnic origin (Walker 1995).

The Cree people who inhabit the model forest belong to the community of First Nations who strive for political autonomy, and for access to their traditional homelands and related forest resource development opportunities. The aspirations of First Nations, their current socio-economic discrimination, and the current forest ownership pattern all reflect the colonial legacy. A good understanding of this legacy and its effects on resource management is therefore pivotal to advancing sustainable management concepts in the boreal forest of Saskatchewan. Clapham (1985) identified four aspects of colonial rule: (i) territorial boundaries where none had existed before; (ii) centralized administration; (iii) a colonial economy and (iv) new social attitudes, institutions and forms of communication between the colonialized peoples themselves. Although all four aspects apply to Saskatchewan, the establishment of new territorial boundaries and the centralization of government administration are most frequently quoted by the local Cree community in the Prince Albert Model Forest.

In terms of the colonial legacy, Canada was under British rule until confederation among the European settlements in 1867. Until this time, the model forest region was almost exclusively inhabited by Cree people. To the Europeans, this land was part of Rupertsland, which stretched across the subarctic, the boreal forest, and the prairies of western Canada. Rupertsland was granted to the Hudson Bay Company in 1670. The company used Rupertsland and its Indian peoples to develop substantial and very profitable fur resources for European markets. Tough (1988) concluded that the related mercantile system created a racial division of labour: with credit, wage rates, gratuities, and control of food surpluses, the Company was able to secure profits, but the return to the Indian people was marginal.

According to Ray (1984), the Indians experienced a shift from a generally stable pre-contact subsistence economy to a fur trade economy that increased resource risks, and decreased the ability of the Indians to deal with scarcity. The increased 


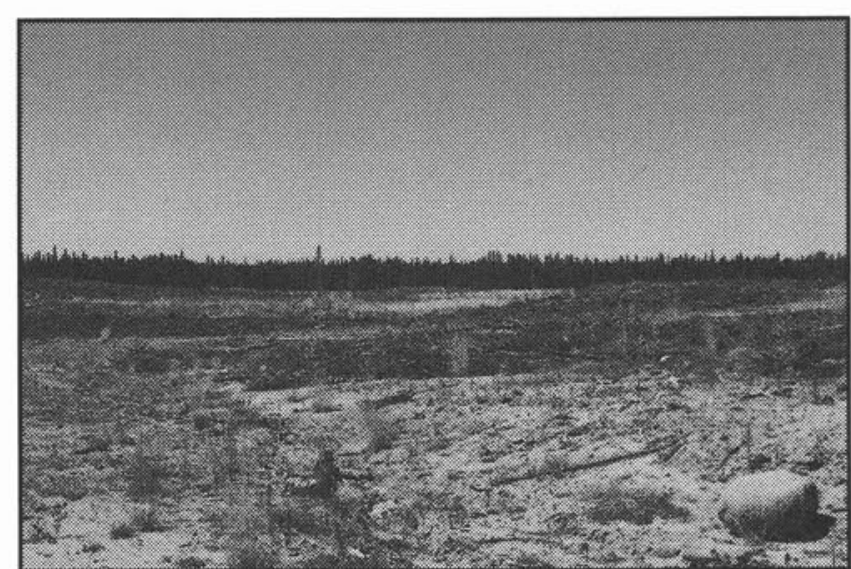

Fig. 2. A recent clear cut area in the Prince Albert Model Forest, SK.

vulnerability made the Indians dependent on a credit system and the resulting welfare assistance that was provided by the Company. Ray concluded that welfare "is deeply rooted in the fur trade", and "was a necessary by-product of several processes: economic specialization by native people, a concomitantly decreasing spatial mobility, European control of food surpluses and the depletion of resources". A marked welfare dependence has persisted until today (Elias 1994).

After confederation, Rupertsland was transferred to the Government of Canada which took a series of legislative and administrative actions to open western Canada for European settlement and economic development. Thus, the boreal forest of western Canada changed from a colony of possession to a colony of settlement. This change of colonial rule dramatically reduced the customary use rights and access to land for the traditional forest dwellers. The transition was further associated with fundamental cultural changes, which resulted for example in culturally biased wildlife conservation legislation. Gottesman (1983) concluded from an evaluation of native hunting and of the Migratory Birds Convention Act that Canadian wildlife conservation primarily served the economic interests and psychological needs of the industrial society.

In the model forest region, the Montreal Lake Cree Nation and other First Nations experienced a deprivation of their customary forest use rights and access due to federal and provincial legislation and policies. These included the creation of large nature conservation areas (e.g. Prince Albert National Park), the general implementation of conservation regulations by the Government of Saskatchewan, and the granting of timber extraction rights to forest-products industries.

In summary, the evidence now available about the effects of the colonial legacy on First Nations in western Canada corroborates the political approach taken earlier by Adams (1975), who related the situation of the Indian people in Saskatchewan to social theories about race, class and caste (Cox 1959). The understanding and recognition of underdevelopment as a result of colonial legacies (Adams 1975; Rodney 1972) should prove useful in developing effective communications among forest stakeholders, and in identifying sustainable forest use options at the policy-making level. Thus, ecologically desirable and innovative forest management practices designed without the participation of First Nations peoples may not survive once their rights to self-government and forest resources have been fully recognized. This conclusion is consistent with Rotmans et al. (1994), who stated that different cultural perspectives may translate into different preferences for the operational definition of sustainable development.

\section{Rising Use of Forest Resources}

The model forest area is located between the North Saskatchewan and the Churchill Rivers, which were the major transportation arteries during early resource exploitation. Access from the model forest through tributaries was limited. The development of road infrastructure provided the basis for a growth of fur trade, fishing and hunting, tourism, and forest-product industries in the 20th century.

Fur trading posts were established in the 1930 s but harvest of fur bearing animals decreased most likely for economic reasons, during the last decades (Sentar 1995). Tourism increased steadily since road access was provided in 1927. There were about 177,000 visitors at Prince Albert National Park in 1993-1994. Timber harvest levels showed a marked increase with the addition of a pulp mill to the regional wood-processing industry in 1967 . The harvest peak was about $240,000 \mathrm{~m}^{3}$ $\mathrm{yr}^{-1}$ at the beginning of this century. The pulp mill demand was about $1,700,000 \mathrm{~m}^{3}$ of wood in 1993 . This rise in wood demand for pulp and paper production occurred later than in other parts of Canada, e.g., 10 to 20 years later than in interior British Columbia (Cohen 1994).

Thus tourism and timber harvesting have been the two most significantly rising forest uses in the Prince Albert Model Forest, and have increased human interventions in this forest, especially the development of infrastructure (roads) and organized fire suppression since 1945. The latter has had an apparent effect because the forest age class distribution implies a dramatic reduction in the forest renewal rate (Fig. 4).

The forest use by local residents for domestic production (Fig. 5) has not been quantified, but it can be significant for the economic well-being of northern communities (Elias 1994). There is, however, a shift from traditional multiple use with minimal intervention of the traditional Cree society to single use with increasing intervention, e.g. tourism in Prince Albert National Park or commercial timber production. This shift reflects a typical paradigm of industrial forest development (Radkau and Schäfer 1987).

\section{Management Structure and Process}

The Prince Albert Model Forest Association was incorporated as a non-profit organization with resources provided by Canada's "Partners in Sustainable Development of Forests" program. This program explicitly directs forest management to becoming more sustainable with reduced government involvement in the delivery of forest development programs. This also reflects a privatization pressure on the public forestry sector in Canada as federal and provincial governments face fiscal restraint.

The stakeholders participating in the Prince Albert Model Forest include: Canadian Institute of Forestry (Saskatchewan Chapter), Federation of Saskatchewan Indian Nations, Montreal Lake Cree Nation, Prince Albert Grand Council, Parks Canada (Prince Albert National Park), Saskatchewan Environment and Resource Management, and Weyerhaeuser Canada Ltd. 


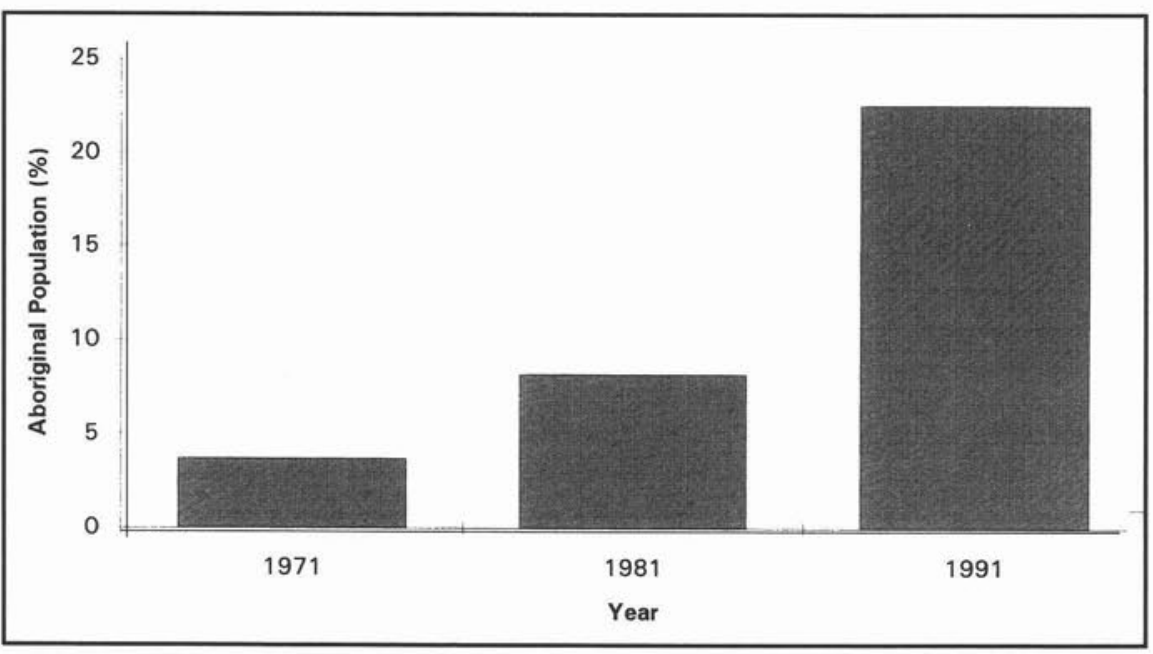

Fig. 3. Percentage of the aboriginal population in the City of Prince Albert, SK. The total city population was 28,464 in $1971,30,995$ in 1981, and 34,181 in 1991 (Kulshreshtha et al. 1994).
(Saskatchewan Division). The area of the Prince Albert Model Forest represents about 1\% of Saskatchewan's forest, and includes the reserve land of only one of the 72 First Nations in Saskatchewan. As such, the Prince Albert Model Forest can be classified as a micro-level development project (Dixon 1991), but it crosses three jurisdictions (federal, provincial and First Nation).

The model forest provides representatives of the Montreal Lake Cree Nation as well as regional and provincial First Nations with a historical opportunity to establish a continuous dialogue on resource planning and management with government and industry. The decision-making authority for land use remains, however, the exclusive privilege of government. The management process is further influenced by the obligations and rights of the partners that existed prior to the establishment of the model forest.

The Association has a board of directors, with equal representation from all seven partners, the main task of which is to develop a plan (strategy) for sustainable forest use. The board delegates the provision of research and communications support to full-time model forest staff and research associates. However, all model forest activities reflect a strong stakeholder ownership of program content and delivery mechanisms.

The Canadian Forest Service (CFS) as the federal funding agency also maintains control of program content and closely monitors cash-flow of the Association. In addition, the CFS offers its own forest research and development services in Saskatchewan. Such concentration of control and delivery functions may result in information asymmetries (Henry 1988) which in turn may adversely affect the Association's performance and effectiveness.

However, the federal model forest programme has established in Saskatchewan some equity among stakeholders of different ethnicity and wealth. In fact, it initiated a process of localizing forest management (Behan 1988).

\section{Operational Sustainability}

Baskerville (1986) summarized an audit of management of the crown forests of Ontario as follows: "There is insufficient responsibility and accountability in the system". Similarly, Tzschupke (1993) points out, that for German forest management, practical evaluation of forest management achievements is only partially guaranteed because an operational goal system is often missing and because non-timber goals of forestry are not taken into consideration. Thus the revitalized notion of forest sustainability will not have a lasting effect on forest planning and management unless responsibilities and accountabilities are clearly defined at the operational level.

The goal of operational sustainability has been defined as a permanent, continuous, and even flow of forest benefits (Dengler 1982; Kurth 1994). Approaches to operational sustainability can be broadly categorized in scientific/technical approaches and in policy-making. Scientific/technical approaches support the integration of environmental aspects into forestry and also enhance the accountability of forest management. Policymaking is the basis for tackling primarily the human dimension of sustainable forest use and the assignment of responsibilities. The scientific/technical approaches consider the forest landbase, productivity and value. Each approach to sustainability has characteristic measures and requires different (research) activities for strategy development and the assessment of strategic options.

Scientific/technical approaches toward sustainability were conceived by forest dependent communities, resource managers and forest scientists (e.g. Cotta in Germany) in response to rising pressure on forest resources at least since the late middle ages. These approaches have been successfully used in sustaining forests. Pantin (1991) states that scientific/technical arguments for policies aimed towards sustainable development rest on the uncertainty of the upper limits of environmental change, but there is conceptual clarity that such limits exist.

We suggest that forest ownership, economic development and economic philosophies are important aspects of sustainable policy-making in the Prince Albert Model Forest. In general, such policy-making has a long history. However, a review of the social and economic context of sustainable policy-making and its effectiveness casts doubt that sustainablility was always the real motive. Radkau and Schäfer (1987) argued that sustainability was often used as a pretext to deprive communities of their customary forest access rights, and to convert multiple use forests into single use forests in order to capitalize on industrial developments and related state revenues. Similarly, Dixon and Fallon (1989) noted that terms such as sustainable development are exceedingly difficult to define and frequently result in contradictory policy advice. The problem is compounded by the growing real- 
Fig. 4. Estimate of the age and patch size class distribution of even-aged forest patches in the timber-productive Crownland of the Prince Albert Model Forest, SK. Patch Size was calculated on the basis of the 1984 Saskatchewan Forest Inventory using ArcInfo GIS.

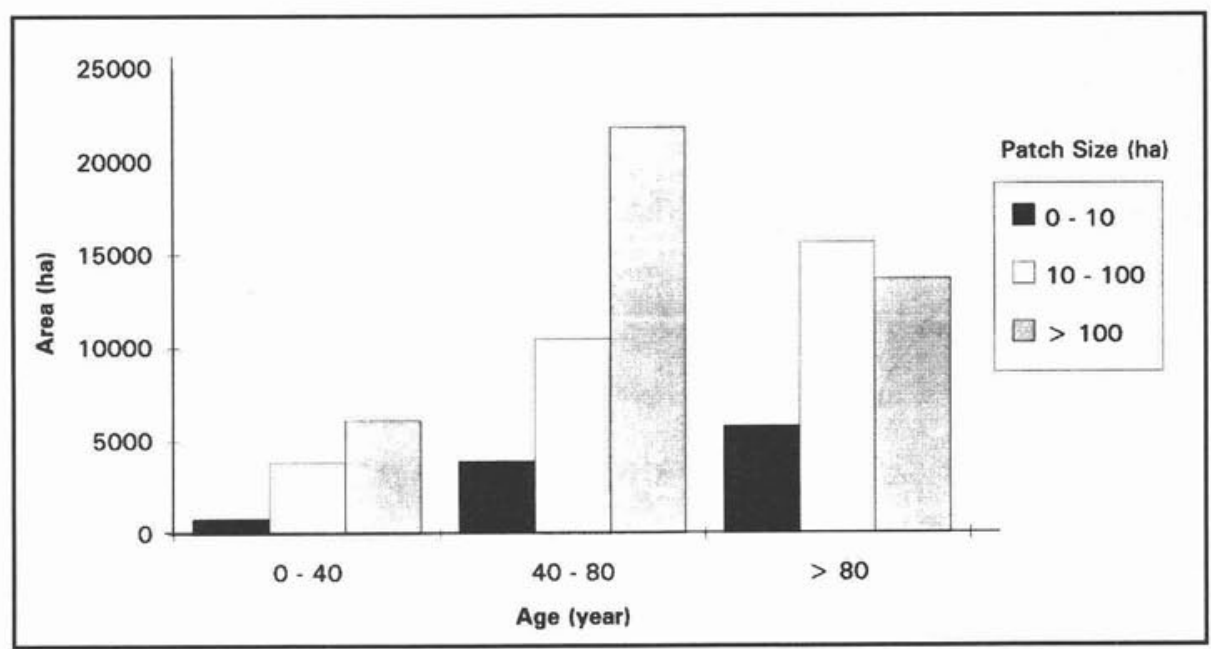

ization of the inter-connectedness of countries, government policies, and ecosystems (Dixon 1991). Repetto and Gillis (1988) stated that policies of governments have often been inimical to the rational utilization of valuable forest resources. Hence, policy-making is as critical for sustaining the environment and forest ecosystems as our emerging understanding of scientific/technical sustainability criteria and issues (Pantin 1991; Brabänder 1994).

\section{Landbase Approach}

The landbase approach divides the landbase into forest management units that are allocated to pre-determined harvest periods. It is the oldest and most reliable approach to ensure permanency and continuity, and an even flow of the sum of all forest benefits through the long term. This approach is spatially and temporally explicit and makes forest users accountable because managers and auditors only have to keep track of area and related use in principle. The high level of resolution $(1: 12,500)$ and the availability of digital forest inventories further enhance the possibility for accountable and sustainable land use planning and management for the Prince Albert Model Forest.

Research activities focus on surveys that incorporate ecological features and traditional landuse pattern within the existing forest inventory. The applications of geographic information systems, habitat suitability models, and forest simulation models have become pivotal to zone the forested landscape properly in order to meet multiple use objectives. Simple two-dimensional diagrams (Fig. 4) are used to assess the state of the resource against multiple use targets. For example, knowledge about stand age and patch size distributions is paramount to projecting the area that will reach timber harvest maturity and availability during a given time period. This same knowledge can also be used for projecting biodiversity and habitat suitability (Franklin and Forman 1987).

The ultimate challenge is to sustain the dynamically changing spatial order (Wagner 1907) of the forest. Hence, use options derived from the landbase approach must be assessed against the operational compatibility of land use options with the environmental, cultural and dynamic integrity of the forest ecosystem. Such an approach should enhance simple area control which still prevails in the planning and review of many Canadian forestry operations.
Garman and Bradshaw (1994) and Ripple et al. (1991) proposed independent variables that quantitatively describe geometric and structural properties of the forested landscape, e.g. patch size. There are implications about meeting spatial order constraints such as patch size. For example, about $25 \%$ of the commercially timber-productive landbase in the model forest has almost exclusively been harvested using large (up to $100 \mathrm{ha}$ ) clear cuts during the last 25 years. For cultural and ecological reasons, the remaining $75 \%$ of the forest may no longer be harvested by creating a regular patch work of large clear cuts. In fact, forest management needs to plan for a significant aggregation of harvest areas to sustain ecological and cultural functions that depend on large patch size which is a typical feature of the Prince Albert Model Forest (Fig. 4). Hunter (1993) proposed that managed boreal forests should mimic the patch size distribution that is generated by natural forces, as documented by Foster (1983) and Payette et al. (1989) for boreal regions in Quebec and Labrador.

The Prince Albert Model Forest has so far used a combined intuitive/scientific approach to find an approximate spatial order optimum by engaging traditional users, forest industry and scientists in the timber harvest planning process (Fig. 6). The process will increasingly be supported by decision support tools that simulate constrained harvest schedules to meet timber as well as non-timber objectives (Dahlin and Sallnäs 1993; Nelson and Finn 1991).

\section{Productivity Approach}

The productivity approach intends to ensure an even flow of forest benefits by keeping timber yields at a constant level for a given management area. This approach requires, however, long-term experimental observations of stocks and flows in the forest ecosystem in order to determine the environmental integrity and the sustainability of consumptive forest use. The productivity approach is not spatially explicit and grants, therefore, high operational flexibility (Kurth 1994).

The development of comprehensive empirical growth and yield databases (historical bioassays) is still at an early stage in the Prince Albert Model Forest because managed forest stands are young. Thus the model forest does not have sufficient data to rely solely on this approach. However, the present age class distribution (Fig. 4) suggests that the flow of timber and related benefits will be uneven if clear cutting of mature and 


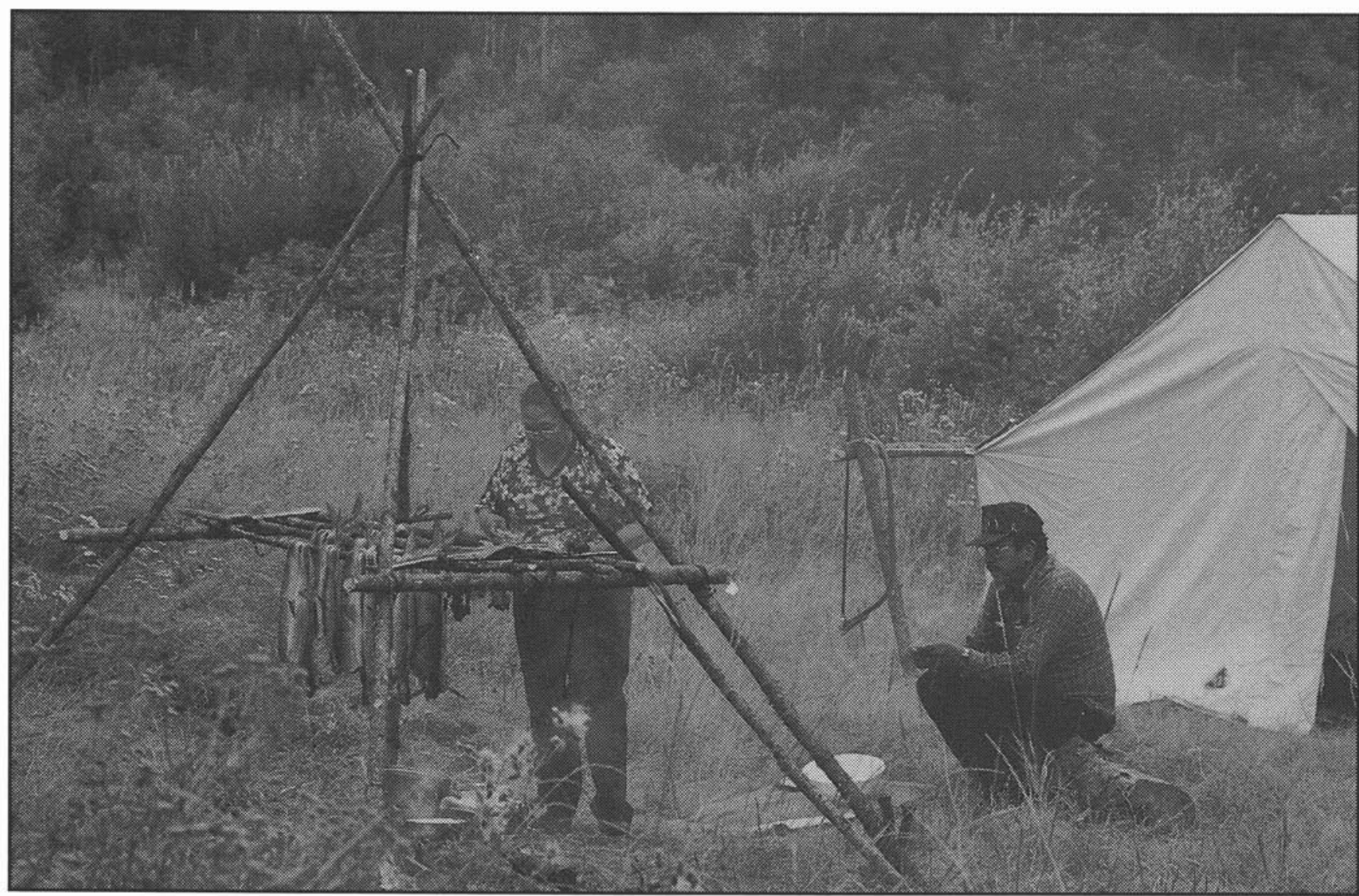

Fig. 5. Traditional users preserving their fish harvest in the Prince Albert Model Forest, SK.

over-mature stands continues to be the preferred method of timber production.

The productivity approach with its observations of stocks and flows also allows forest planners and managers to learn about the internal and external inter-connectedness of ecosystems (Kimmins 1986; Ulrich 1984, 1986) and society (Bossel 1989, 1990). Such knowledge will enhance the interpretation of forest site classification schemes and related yield observations(Bouman 1991), and the simulation of the dynamics of natural forests (Bossel and Krieger 1991). A process-based growth model is used in the Prince Albert Model Forest to assess and to examine long-term productivity implications of planning options derived from the dynamic zoning of the landbase and of global environmental changes. Thus the productivity approach should make forestry operations more responsive to ecosystem changes than traditional volume control.

\section{Forest Value Approach}

The forest value approach refers to sustaining an even flow of monetary benefits from the forest. The approach was originally limited to exchange values. For example, accessibility and timber utilization potential are considered in the allocation of harvest areas to the pre-determined time periods. This would avoid a decrease in profits through time.

Researchers and decision-makers are now attempting to determine (i) the total value (i.e. sum of all exchange and use values) of the ecosystem or (ii) the total cost of extracting forest resources by attaching shadow prices to use values or non-mark- benefits. Dixon (1991) views the valuation and pricing of natural resources and environmental services as an essential component of analyzing resource management. Repetto and Gillis (1988) stated that the practice of not assigning money values to non-market benefits of forests accounts for much of the worldwide tendency to undervalue natural forest assets.

Pricing of use values has resulted in substantially increased monetary value of boreal forests in Scandinavia (Hoen and Winther 1993; Mattsson and Chuanzhong 1993). Since recreation has emerged as one of the most significant use values of the model forest (Fig. 7), a study is under way that attaches monetary values to specific recreational uses of the model forest (Loewen and Kulshreshtha 1995). Not only will this study provide a more comprehensive valuation of the forest, it will also provide an indication of the financial contribution that sustainable forest planners and managers can make to GNP, thereby encouraging society to invest in the advancement and practical implementation of forest sustainability.

Some economists express concern that shadow pricing of use values will be used to justify the unjustifiable - irreversible environmental damage (Pantin 1991). Norgaard (1989) explains the dilemma of environmental accounting as follows: "the goal of environmental accounting is to provide aggregate indicators of people's willingness to improve the quality of the environment and sustain the future. If people are not very willing, then the environment is not very valuable .... Environmentalists, on the other hand, argue that they are ethically compelled to protect other species and to seek sus- 


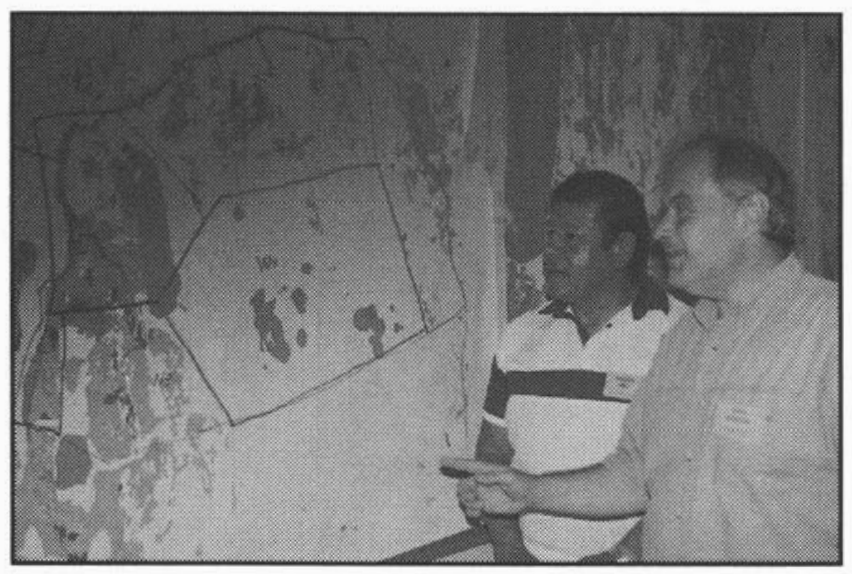

Fig. 6. Industrial and traditional forest users undertaking a joint timber harvest planning exercise for an area in the Prince Albert Model Forest, SK.

tainable development. Sustainability for them should be a constraint on, or at least a separate objective of, development strategies". Similar concerns have been expressed by some participants of the Prince Albert Model Forest.

\section{Forest Ownership}

Ownership policies regulate, directly, who has access to the forest and, indirectly, the degree of self-sufficiency of people living in and off the forest. For example, reducing access may well result in greater welfare dependence of the Montreal Lake Cree Nation. Furthermore, Repetto and Gillis (1988) concluded that the centralization of property rights to forest lands often undermined local rules governing access and use. It also removed local incentives for conservation and saddled governments with far-flung responsibilities beyond their administrative capabilities.

Lal (1994) suggested the following: "participation is the institution that links forests, people and governments. As an institution, participation should replace government in microlevel planning". Since the model forest is intended to operate at the micro-level, it could therefore serve to demonstrate how the currently dominating government-owned management concepts could be converted into a more localized form of ownership and management concept that can be sustainably supported by forest stakeholders and local communities. The dialogue among the Prince Albert Model Forest partners, however, has not sufficiently evolved to fully address or accommodate such goals and concepts.

\section{Economic Development}

Historically, forests have provided economic development opportunities in themselves. However, they also have been liquidated in many cases to make way for non-forest development opportunities. It is now clear that economic development can only contribute to achieving sustainable forest use once the economic stability of local communities is tied to the stability of the forest ecosystem. For example, Orr and Buongiorno (1991) found that employment stability increased in small counties of Oregon, Washington, Michigan, Wisconsin and Arkansas with increased forest industrial activity, increased rate of economic growth, increased industrial diversity, the presence of small firms, and diversity of firm size. Thus economic diversification appears to be an important measure for assessing sustainable development of forest-based communities.

Thus far, provincial and federal policy-makers have generally failed, or have been unable to provide First Nations peoples with opportunities to participate in the dominant forest uses, i.e. tourism and forestry. This situation, however, appears to be changing. For example, stakeholders within the Prince Albert Model Forest have advanced a bilateral dialogue to the extent that mutually beneficial and sustainable economic opportunities can now be identified (Bouman, D.T. 1994). It is hoped that this will help to re-establish a tangible link between community well-being and forest ecosystem stability.

Deficiencies in education and skill training have often been quoted as major obstacles to increasing First Nations participation in economic development. The Prince Albert Model Forest therefore supports a formal connection between economic development and the provision of educational services and skill training. Aiming at least some of the educational services at increasing cultural self-identity has been found to be a critical factor in the successful participation of ethnic minorities (Ogbu 1988). The Prince Albert Model Forest hopes to instill in the young Cree generation an awareness of the value of their elders' traditional forest use knowledge, and to help the reformulation of that knowledge in a modern context. The latter would facilitate skill training in advanced forest management technologies.

\section{Economic Philosophies}

There remains the question of who will bear the cost for maintaining environmental quality in the quest for sustainable development (Pantin 1991). Brabänder(1994) offered the following philosophy: "The ways and means selected for utilizing resources on a sustainable basis have a great influence on the practical achievement of this goal. From an economic standpoint, the market-oriented approach is best. Legal regulations should be limited to creating the overall conditions within which market forces can be given free rein." Underwood and King (1989) point to the steady-state school of environmental economics for which questions of absolute scarcity take primacy over the aforementioned neoclassical focus on problems of relative scarcity in policy analysis. The authors conclude that policy prescriptions resulting from this philosophy are not necessarily 'market bound' and may therefore transcend the institutional arrangements common in free-market societies.

Gottfried et al. (1994) concluded from a review of sustainable development and forest resource management in Costa Rica that policy-makers must be clear about what they want to sustain, who receives the benefits, and who bears the costs of sustainable development efforts. Thus the economic philosophy, when applied to policy-making at the micro-level, tends to be reflected in the degree of internalization and externalization of incremental costs for sustainable forest use and in the allocation of benefits. Although there may be precedence in that forest industry and government established a trust fund prior to the foundation of the model forest to ensure reforestation of harvested areas, economic philosophies of the stakeholders have yet to be discussed, clarified and defined for the Prince Albert Model Forest. The process is supported through public consultation with non-governmental organizations in Saskatchewan, and research on cultural values of people who inhabit or visit the model forest region. 


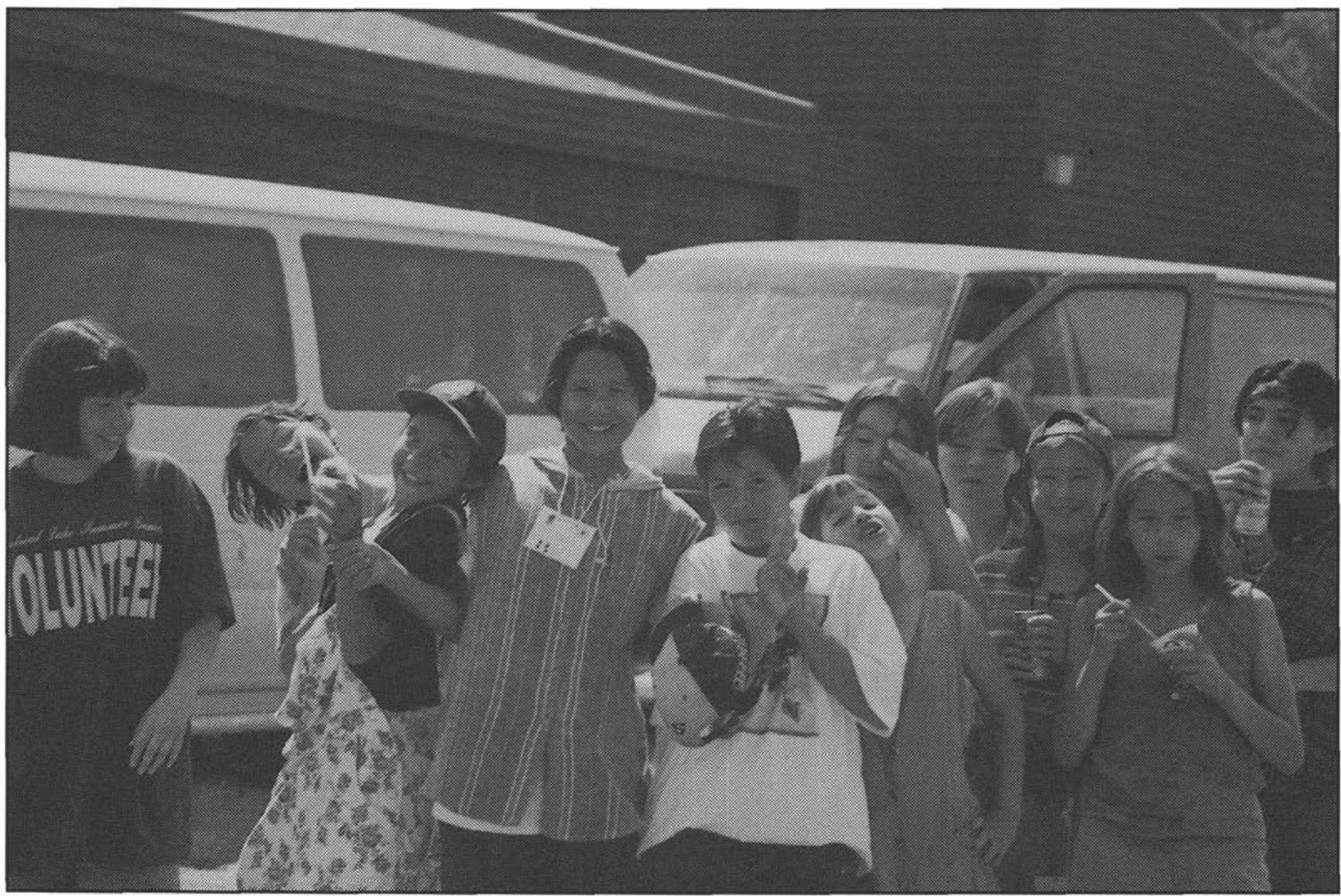

Fig. 7. The children of the local Cree community enjoy the recreational value of the Prince Albert Model Forest, SK.

\section{Conclusions}

Although inter-connectedness of ecosystems (Dixon 1991) and delays in the ecosystem response to environmental degradation (Pantin 1991) have been recognized as being critical to sustainable development, these phenomena are still far from being adequately incorporated into operational planning and management for sustainable forest use. This deficiency should raise concern, because the efficiency of forest harvesting operations seems to have grown faster than the ecological knowledge base. The spatial order of the forest, however, has received full recognition, and operationalization of the spatial order reached an advanced stage that allows the constraint of timber harvesting vis-à-vis habitat requirements and biodiversity.

Sustainability of the Prince Albert Model Forest is challenged socially by a colonial legacy of racial divisions, territorial boundaries and centralized forest administration. The resultant lack of social cohesiveness may jeopardize the sustainability of the Prince Albert Model Forest if these two premises hold true: (i) the pressure on the boreal forest resource will continue to rise (Perez-Garcia 1993), and (ii) different cultural perspectives may translate into different development preferences (Rotmans et al. 1994). Thus social cohesiveness as a cornerstone for sustainable development should gain full appreciation among the policy-making authorities. Furthermore, the province of Saskatchewan appears to be in need of an institutional framework that would foster and finance the evolution of localized policy-making in pursuit of sustainable for- est use. Similar to what is beginning to emerge in other areas of Canadian society, e.g. education (Bouman, C.E. 1994), localized decision-making boards might be supported by levying fees from those who derive (particularly monetary) benefits from utilizing forest resources. The mandate of localized sustainable development boards should be twofold: (i) continuous advancement of operational sustainability for forested areas, and (ii) development of a cooperative approach for enhancing compliance with sustainability policies.

Achieving sustainability in the Prince Albert Model Forest may be compromised by a high level of government involvement and overall management responsibility (e.g. fisheries, forestry, and wildlife management). Rauch (1992 in Ellenberg et al. 1993) indicated that sustainable development problems can arise when cooperating with government agencies because of: (i) diverging interests regarding use of funds; (ii) limited possibilities for improving the services offered by government organizations at the regional level; and (iii) limited availability of alternatives to government executing institutions.

In summary, the development of a sustainability-oriented forest use strategy for the Prince Albert Model Forest will have to consider the laws of the ecosystem, unstable framework conditions, and the limitations of the project-executing institutions (Rauch 1992 in Ellenberg et al. 1993).

\section{Acknowledgement}

The authors gratefully acknowledge the support provided by the Prince Albert Model Forest Association and the 
Canadian Forest Service. The content of this publication does not reflect the views held by partners of the Prince Albert Model Forest Association. We are grateful to the members of the Association and the Won Ska Cultural School who have shared with us their knowledge of northern peoples, forests and forest management. We also like to thank Dr. P. Arp, University of New Brunswick, and Dr. H.D. Brabänder, University of Göttingen, for reviewing an initial draft of this manuscript. We are thankful to the Forestry Branch of Saskatchewan Environment and Resource Management for providing forest inventory data. King Motion Pictures Inc. is acknowledged for providing pictures of the Prince Albert Model Forest and its people.

\section{References}

Adams, H. 1975. Prison of Grass: Canada from a Native Point of View. Fifth House. Saskatoon, SK. 206 p.

Anderson, D.W. and J.G. Ellis. 1976. The soils of the Provincial Forest Reserves in the Prince Albert Map Area. Extension Publication 261, Saskatchewan Institute of Pedology, University of Saskatchewan, Saskatoon, SK 126 p.

Baskerville, G.L. 1986. An audit of management of the Crown Forests of Ontario. Ontario Minister of Natural Resources, Toronto, ON. 97 p.

Behan, R.W. 1988. A Plea for constituency-based management. American Forests July/August:46-48.

Bossel, H. 1989. Simulation dynamischer Systeme - Grundwissen, Methoden, Programme. Vieweg, Braunschweig, Federal Republic of Germany, p. 310.

Bossel, H. 1990. Umweltwissen - Daten, Fakten, Zusammenhänge. Springer, Hamburg, Federal Republic of Germany. 169 p.

Bossel, H. and M. Krieger. 1991. Simulation model of natural tropical forest dynamics. Ecological Modelling 59: 37-71.

Bouman, C.E. 1994. Fees in public schools. Unpublished doctoral thesis, University of British Columbia. 285 p.

Bouman, O.T. 1991. Quantitative Aspekte der Waldernährung in Forststandorten mit Bodenversauerung und anthropogener Immissionsbelastung - dargestellt am Beispiel des Westharzes. Doctoral thesis published in: Berichte Forschungszentrum Waldökosysteme Reihe A Vol. 65, Göttingen, Federal Republic of Germany. 176 p. Bouman, O.T. 1994. Second Annual Report of the Prince Albert Model Forest Association, Inc. Prince Albert Model Forest Association, Inc., Prince Albert, SK. 94 p.

Brabänder, H.D. 1994. The value of forests in economic and noneconomic terms. In: Proceedings of Conference on Security and Cooperation in Europe Seminar of Experts on Sustainable Development of Boreal and Temperate Forests. Montreal 27 September - 1 October 1993. Natural Resources Canada, Ottawa, ON.

Brand, D.G. and A.M. LeClaire. 1994. The Model Forests Programme: International Cooperation to Define Sustainable Management. Unasylva 45: 1-8.

Clapham, C. 1985. Third world politics. Routledge, London, UK. $197 \mathrm{p}$.

Cohen, D.H. 1994. A History of the marketing of British Columbia softwood lumber. Forestry Chronicle 70: 578-584.

Cox, O.C. 1959. Class, caste and race. Monthly Review Press, New York. 330 p.

Dahlin, B. and O. Sallnäs. 1993. Harvest scheduling under adjacency constraints - a case study from the Swedish Sub-alpine Region. Scand. J. For. Res. 8: 281-290.

Dengler, A. 1982. Waldbau auf ökologischer Grundlage. Fifth edition. Paul Parey, Hamburg, Federal Republic of Germany. 280 p. Dixon, J.A. 1991. Project appraisal: Evolving applications of environmental economics. In: Girvan, N.P. and D.A. Simmons (Eds.): Caribbean ecology and economics. University of the West Indies, Mona, Kingston, Jamaica.
Dixon, J.A. and L.A. Fallon. 1989. The concept of sustainability: Origins, extensions, and usefulness for policy. Society and Natural Resources 2(2).

Duinker, P.N., P.W. Matakala, F. Chege and L. Bouthillier. 1994. Community forests in Canada: An overview. The Forestry Chronicle 70: 711-720.

Elias, P.D. 1994. Northern communities, economics and development. University of Lethbridge, Lethbridge, AB.

Ellenberg, L., J. Esser, M. Niekisch, M. Scholz et al. 1993. Action areas for technical cooperation in the field of nature conservation. Deutsche Gesellschaft für Technische Zusammenarbeit $\mathrm{GmbH}$, Eschborn, Federal Republic of Germany. 39 p.

Foster, D.R. 1983. The history and pattern of fire in the boreal forest of southeastern Labrador. Can. J. Bot. 61: 2459-2471.

Franklin, J.F. and R.T.T. Forman. 1987. Creating landscape patterns by forest cutting: Ecological consequences and principles. Landscape Ecol. 1: 5-18.

Garman, S.L. and G.A. Bradshaw. 1994. Landscape analysis in ecosystem management. In: Indicators of Sustainable Development Workshop, Cornerbrook, NFLD, Natural Resources Canada, Ottawa, ON. pp. 63-71.

Gottesman, D. 1983. Native hunting and the Migratory Birds Convention Act: Historical, political and ideological perspectives. Journal of Canadian Studies 18: 67-89.

Gottfried, R.R., C.D. Brockett, and W.C. Davis. 1994. Models of sustainable development and forest resource management in Costa Rica. Ecological Economics 9: 107-120.

Henry, R. 1988. Privatization and the state enterprise sector in Trinidad and Tobago: Markand nonmarkissues in a plural political economy. In: D.J. Gayle and J.N. Goodrich (eds.): Privatization and deregulation in global perspective. Quorum Books, New York.

Hoen, H.F. and G. Winther. 1993. Multiple use of forestry and preservation of coniferous forests in Norway. Scand. J. For. Res. 8: 266-280.

Hunter, M.L. 1993. Natural fire regimes as spatial models for managing boreal forests. Biological Conservation 65: 115-120.

Kabzems, A., A.L. Kosowan and W.C. Harris. 1986. Mixedwood section in an ecological perspective, Saskatchewan. Technical Bulletin No. 8, Canada-Saskatchewan Forest Resource Development Agreement, Natural Resources Canada, Edmonton, AB. 122 p. Kimmins, J.P. 1986. The need for a hybrid model such as FORCYTE11. In: G.I. Agren (Ed.). Predicting the consequences of intensive forest harvesting on long-term productivity. Swed. Univ. Agric. Sci. Report nr. 26: 31-84.

Kimmins, J.P. 1992. Balancing act - environmental issues in forestry. UBC Press, Vancouver, BC. 244 p.

Kulshreshtha, S.N., J.K. Siemens, W.S.M. Doell and H.V. Walker. 1994. Economic perspective on the Prince Albert Model Forest Region of Saskatchewan. Report prepared for the Prince Albert Model Forest Association, Prince Albert, SK. 212 p.

Kurth, H. 1994. Forest management planning — sustainable management and regulation of forest resources. [Forsteinrichtung Nachhaltige Regelung des Waldes]. Deutscher Landwirtschaftsverlag, Berlin, Federal Republic of Germany. 592 p.

Lal, J.B. 1994. Forestry planning: New challenges in Indian forestry. Paper presented at the Canadian Forest Service/FAO Satellite Meeting: An Appropriate Framework for Forestry Sector Planning Incorporating Environmental Concerns, Private and Community Interests. 18-21 September, Anchorage, AK., FAO, Rome, Italy. Loewen, K.G. and S.N. Kulshreshtha. 1995. Economic value of the recreation experience at the Prince Albert National Park of Saskatchewan. Report prepared for the Prince Albert Model Forest Association, Prince Albert, SK. 83 p.

Mattsson, L. and L. Chuanzhong. 1993. The non-timber value of northern Swedish forests. Scand. J. For. Res. 8: 426-434.

Natural Resources Canada. 1994. Model Forest Program - year in review 1993 -1994. Natural Resources Canada, Hull, PQ. 17 p. 
Nelson, J.D. and S.T. Finn. 1991. The influence of cut-block and adjacency rules on harvest levels and on road networks. Can. J. For. Res. 21: 595-600.

Norgaard, R.B. 1989. Three dilemmas of environmental accounting. Ecological Economics 1: 303-314.

Notzke, C. 1994. Aboriginal peoples and natural resources in Canada. Captus University Publications. 337 p.

Ogbu, J.U. 1988. Diversity and equity in public education: Community forces and minority school adjustment and performance. In: R. Haskins and D. Macrae (Eds.): Policies for America's public schools: Teachers, equity and indicators: $127-170$. Ablex, NJ.

Orr, B. and J. Buongiorno. 1991. Forestry and employment instability in counties of the United States. Journal of World Resource Management 5: 115-131.

Pantin, D.A. 1991. The role of economic analysis/policy in sustainable development: A markincentive approach. In: N.P. Girvan and D.A. Simmons (Eds.): Caribbean ecology and economics. University of the West Indies, Mona, Kingston, Jamaica.

Payette, S., C. Morneau, L. Sirois and M. Desponts. 1989. Recent fire history of the northern Quebec biomes. Ecology 70: 656-673. Perez-Garcia, J.M. 1993. Global forestry impacts of reducing softwood supplies from North America. Working Paper 43, Centre for International Trade in Forest Products, University of Washington, Seattle, WA. 35 p.

Radkau, J. and I. Schäfer. 1987. Holz - Ein Naturstoff in der Technikgeschichte. Rowohlt, Hamburg, Federal Republic of Germany. $313 \mathrm{p}$.

Rauch, T. 1992. Strategieelemente für eine Umsetzung des LREKonzeptes unter veränderten Rahmenbedingungen. LRE aktuell, Berlin, Federal Republic of Germany.

Ray, A.J. 1984. Periodic shortages, native welfare and the Hudson's Bay Company, 1670-1930. In: S. Krech III (Ed.): The Subarctic fur trade: Native social and economic adaptations. University of British Columbia Press, Vancouver, BC. pp. 1-20.

Repetto, R. and M. Gillis. 1988. Public policies and the misuse of forest resources. Cambridge University Press, Cambridge, MA. $432 \mathrm{p}$.
Ripple, W.J., G.A. Bradshaw and T.A. Spies. 1991. Measuring forest landscape patterns in the Cascade range of Oregon, USA. Biological Conservation 57: 73-88.

Rodney, W. 1972. How Europe underdeveloped Africa. BogleL'Ouverture. London, UK. 316 p.

Rotmans, J., M.B. van Asselt, A.J. Bruin and H.J. de Vries. 1994. Global change and sustainable development - a modelling perspective for the next decade. RIVM Report no. 461502004 , National Institute of Public Health and Environmental Protection, Bilthoven, The Netherlands. 80 p.

Sentar. 1995. Historical/cultural study of the Prince Albert Model Forest. Report prepared by Sentar Consultants Ltd. for Prince Albert Model Forest Association, Inc., Prince Albert, SK. 219 p.

Thomas, D.C. and J. Schaefer. 1991. Wildlife co-management defined: The Beverly and Kaminuriak Caribou Management Board. Rangifer, Special Issue no. 7: 73-89.

Tough, F. 1988. The northern fur trade: A review of conceptual and methodological problems. Musk-Ox 36: 66-79.

Tzschupke, W. 1993. Der Zielbezug in der forstlichen Erfolgskontrolle. Forstarchiv 64: 20-24.

Ulrich, B. 1984. Effects of air pollution on forest ecosystems and waters - the principles demonstrated at a case study in central Europe. Atmospheric Environment 18: 621-628.

Ulrich, B. 1986. Die Rolle der Bodenversauerung beim Waldsterben: Langfristige Konsequenzen und forstliche Möglichkeiten. Forstw. Cbl. 105: 421-435.

Underwood, D.A. and P.G. King. 1989. On the ideological foundations of environmental policy. Ecological Economics 1: 315-334. Wagner, C. 1907. Die Grundlagen der räumlichen Ordnung im Walde. Lauppsche Buchhandlung, Tübingen, Federal Republic of Germany. $387 \mathrm{p}$.

Walker, H.V. 1995. Historical review of the economic impacts of changing resource use on communities in the Prince Albert Model Forest Region. Report prepared by Hugh Walker Consulting Enterprises Ltd. for Prince Albert Model Forest Association, Prince Albert, SK. 60 p. 